\title{
AMCP Partnership Forum: Helping patients anticipate and manage drug costs
}

\section{SUMMARY}

Prescription drug spending has been rising in recent years and is expected to continue to grow over the next decade. As such, concerns regarding patient affordability and access are areas of focus across the health care industry.

In response to these concerns, AMCP held a multidisciplinary stakeholder forum March 12-13, 2020, in Alexandria, Virginia, to consider the implications and opportunities of various existing and potential drugpricing reforms. Participants represented diverse sectors of the health care industry including health plans, patient advocacy organizations, employers, integrated delivery systems, pharmacy benefit managers (PBMs), specialty pharmacies, and biopharmaceutical companies. During the live forum, participants evaluated prescription affordability challenges and potential reforms, possible solutions to improve transparency and help patients understand and manage their drug costs, and the future of affordability in pharmacy. These proceedings summarize the key topics and discussion points from the forum.

Ultimately, participants recognized that many current pharmaceutical affordability issues are related or are in response to other elements of the health care system. Overall, they called for (a) greater transparency and better alignment among all health care industry stakeholders to place patients in the center of decision making and (b) for any benefit changes or reforms to consider patient access, affordability, and adherence.

\section{Forum participants}

Melissa Andel, MPP, Vice President, Health Policy Applied Policy; Amanda Bain, PharmD, MPH, MBA, Director, Pharmacy and Care Management, The Ohio State University Health Plan; Harold Carter, PharmD, Vice President, Pharma Strategy \& Contracting Express Scripts; Michelle Chang, PharmD, MBA, Director, CVS Health; Erin Darling, Assistant Vice President and Counsel, Federal Policy \& Govt Relations, Merck; Bruce Feinberg, DO, Vice President and Chief Medical Officer Cardinal Health; Lorena Ferrara, Director, Public Policy, Takeda; Stephanie Forbes, PharmD, Clinical Operations Pharmacist, SinfoniaRx; Stephen George, PharmD, MS, Senior Consultant, Milliman; Denise Giamalvol, Vice President, Midwest Business Group on Health; Sean Godar, PhD, MBA, Director and Team Lead, Analytics and Employer Solutions, Employers Health; Joshua Golden, Senior Vice President, Strategy Capital Rx; Dorothy Hoffman, MPP, Access Innovation Lead, Pfizer; Joe Honcz, RPh, MBA, Principal C4i; Scott Howell, DO, MPH\&TM, CPE, Physician AIDS Healthcare Foundation; George Huntley, President, National Diabetes Volunteer Leadership Council; Anna Hyde, Vice President, Advocacy and Access, Arthritis Foundation; Clint Ivie, PharmD, MBA, CSP, Specialty Pharmacy Manager, Intermountain Healthcare; Manjula Jayabalan, PharmD, MBA, Clinical Pharmacist Account
Manager, Magellan Rx Management; Kollet Koulianos, MBA, Senior Director Payer Relations National Hemophilia Foundation; Dana McCormickK, RPh, FAMCP, Director, Pharmacy, Blue Cross Blue Shield Texas; Jennifer Meece, MD, Medical Director, Indiana Medicaid Anthem; Jamie Miller, RPh, System Director, Managed Care Pharmacy Services, Geisinger Health Plan; Heather Odem, PharmD, Director of Pharmacy, Government Programs, Mississippi UnitedHealthcare; Swati Patel, PharmD, MBA, Managing Director, Deloitte Consulting; Annie Schuster, PharmD, Senior Director, Government Pharmacy Clinical Programs, Cigna; Patrick Stone, Vice President, Government Relations and Advocacy, National Psoriasis Foundation; Michael Turchetti, MPP, Director, Policy and Research, Pharmaceutical Research and Manufacturers of America; and Robin Turpin, PhD, Value Evidence Lead, Takeda.

\section{CORRESPONDENCE:}

Nicholas Ladikos, AMCP,

nladikos@amcp.org
J Manag Care Spec Pharm. 2021;27(1):127-32

Copyright $(2021$, Academy of Managed Care Pharmacy. All rights reserved. 


\begin{tabular}{|c|c|c|c|c|c|c|}
\hline & $\begin{array}{c}\text { Assistance } \\
\text { Delivery }\end{array}$ & Eligibility & $\begin{array}{l}\text { Source of } \\
\text { Funding }\end{array}$ & $\begin{array}{l}\text { Specific } \\
\text { Drug? }\end{array}$ & Program Impact & $\begin{array}{c}\text { Potential Market } \\
\text { Response }\end{array}$ \\
\hline $\begin{array}{l}\text { Copay coupon } \\
\text { or copay card }\end{array}$ & $\begin{array}{l}\text { Print/electronic } \\
\text { coupons, debit } \\
\text { cards, and direct } \\
\text { reimbursements }\end{array}$ & $\begin{array}{l}\text { Varies, not } \\
\text { commonly } \\
\text { needs-based }\end{array}$ & $\begin{array}{l}\text { Directly from } \\
\text { pharmaceutical } \\
\text { companies }\end{array}$ & Yes & $\begin{array}{l}\text { Lower OOP cost for patient } \\
\text { Increase adherence to } \\
\text { manufacturer's drug } \\
\text { Tax advantages for the } \\
\text { manufacturers } \\
\text { Undermine plan formulary } \\
\text { strategies }\end{array}$ & $\begin{array}{l}\text { Payer accumulator } \\
\text { adjustment programs } \\
\text { Payer variable copay } \\
\text { programs } \\
\text { Manufacturer alternative } \\
\text { funding methods (e.g. debit } \\
\text { cards, self-filing) }\end{array}$ \\
\hline $\begin{array}{l}\text { Manufacturer- } \\
\text { provided PAP }\end{array}$ & $\begin{array}{l}\text { Drug provided } \\
\text { at low or no cost }\end{array}$ & $\begin{array}{l}\text { Typically } \\
\text { needs-based } \\
\text { (i.e., income } \\
\text { criteria) }\end{array}$ & $\begin{array}{l}\text { Directly from } \\
\text { pharmaceutical } \\
\text { companies }\end{array}$ & Yes & $\begin{array}{l}\text { Lower to no OOP cost for } \\
\text { patient } \\
\text { Increase adherence to } \\
\text { manufacturer's drug }\end{array}$ & $\begin{array}{l}\text { Potential federal } \\
\text { antikickback statute } \\
\text { violation } \\
\text { Payer accumulator } \\
\text { adjustment programs }\end{array}$ \\
\hline $\begin{array}{l}\text { Independent, } \\
\text { charitable PAP }\end{array}$ & $\begin{array}{l}\text { Direct cash } \\
\text { grants }\end{array}$ & $\begin{array}{l}\text { Typically } \\
\text { needs-based } \\
\text { (i.e., income } \\
\text { criteria) }\end{array}$ & $\begin{array}{l}\text { Charitable } \\
\text { foundations } \\
\text { (funded primarily } \\
\text { by manufacturers) }\end{array}$ & No & $\begin{array}{l}\text { Lower OOP cost for patient } \\
\text { Charities routinely run out } \\
\text { of funding }\end{array}$ & $\begin{array}{l}\text { Potential federal antikick- } \\
\text { back statute violation } \\
\text { Payer accumulator } \\
\text { adjustment programs }\end{array}$ \\
\hline $\begin{array}{l}\text { Point-of-sale } \\
\text { rebates }\end{array}$ & $\begin{array}{l}\text { Retail pharmacy } \\
\text { counter via } \\
\text { retail/PBM } \\
\text { system }\end{array}$ & $\begin{array}{l}\text { Patients in } \\
\text { coinsurance/ } \\
\text { deductible phase } \\
\text { of the pharmacy } \\
\text { benefit }\end{array}$ & $\begin{array}{l}\text { Payer/PBM as } \\
\text { negotiated with } \\
\text { manufacturers }\end{array}$ & Yes & $\begin{array}{l}\text { Anticipated } 1 \% \text { or less } \\
\text { increase in plan costs } \\
\text { Patients in HDHP will see } \\
\text { the largest reduction in } \\
\text { OOP }\end{array}$ & $\begin{array}{l}\text { Adoption remains low } \\
\text { Potential increased } \\
\text { premiums as rebate dollars } \\
\text { are reallocated }\end{array}$ \\
\hline
\end{tabular}

$H D H P=$ high-deductible health plan; $O O P=$ out of pocket; $P A P=$ patient assistance program; $P B M=$ pharmacy benefit manager .

According to the Centers for Medicare \& Medicaid Services (CMS) National Health Expenditure Projections, prescription drug spending is expected to continue to grow by up to $5.9 \%$ annually through 2028 , primarily driven by quickly rising drug prices and growth in use and intensity. ${ }^{1}$ The increasing use of specialty drugs, in particular, accounts for the bulk of rising drug prices, with some costing in the hundreds of thousands annually and a select few costing in the millions. ${ }^{2,3}$ At the same time, overall out-of-pocket (OOP) expenditures for health care are also projected to rise, ${ }^{1}$ leaving the burden of costs, including for these higher-cost medications, increasingly on the patient.

Given these concerns around affordability and the resulting potential challenges to patients' ability to access and remain adherent to these expensive therapies, many drugpricing reforms have been proposed and implemented. To evaluate the implications and opportunities of these various reforms, AMCP held a multidisciplinary stakeholder forum March 12-13, 2020, in Alexandria, Virginia, and included participants from health plans, patient advocacy organizations, employers, integrated delivery systems, pharmacy benefit managers (PBMs), specialty pharmacies, and biopharmaceutical companies. Several related topics were addressed including prescription affordability challenges and potential reforms, possible solutions to improve transparency and help patients understand and manage their drug costs, and the future of affordability in pharmacy. These topics and the related discussion by forum participants are described in these proceedings.

\section{Prescription Affordability Challenges and Potential Reforms}

The U.S. health care system, when compared with the respective systems of other wealthy nations, underperforms on a number of quality and care outcomes despite spending much more. ${ }^{4}$ Although spending in all sectors of health care is rising, drug spend, especially for specialty drugs, is rising at a faster rate..$^{2-5}$ As consumers of health care, patients are faced with the increasing burden of helping to absorb these rising costs through mechanisms such as high-deductible health plans (HDHPs). At the same time, patients are facing challenges with wage earnings, making it difficult for them to manage growing OOP costs. ${ }^{6}$

In the discussion that followed the presentation of this material, participants identified some of these cost issues as due to structural challenges within the system itself. For 


\section{FIGURE 1 Example Comparison of Copay Accumulator versus Copay Maximizer}

Benefit Design

- Patient deductible: $\$ 2,000$

- Patient coinsurance: $25 \%$ (\$500/month)

- Patient annual out-of-pocket maximum: $\$ 6,000$

- A pharmacy-only deductible

\section{Prescription Economics}

- Annual cost of medication: $\$ 24,000$

- Copay assistance program: \$0 monthly copay

- Copay assistance program annual maximum benefit: $\$ 16,000$

\begin{tabular}{l|c|c|c}
\hline & $\begin{array}{c}\text { Patient } \\
\text { Assistance } \\
\text { Program Only }\end{array}$ & $\begin{array}{c}\text { With Copay } \\
\text { Accumulator }\end{array}$ & $\begin{array}{c}\text { With Copay } \\
\text { Maximizer }\end{array}$ \\
\hline Patient payment & $\$ 0$ & $\$ 2,000$ & $\$ 2,000$ \\
\hline $\begin{array}{l}\text { Copay assistance } \\
\text { payment }\end{array}$ & $\$ 6,000$ & $\$ 6,000$ & $\$ 16,000$ \\
\hline $\begin{array}{l}\text { Payer payment } \\
\text { Adapted from Drug Channels Institute. }\end{array}$ & $\$ 18,000$ & $\$ 16,000$ & $\$ 6,000$ \\
\hline
\end{tabular}

instance, they acknowledge that at the time of prescribing, it is often difficult to determine the most cost-effective drug option for a specific patient within their given plan due to the lack of availability and usability of data. Additionally, the drug and biologic supply chain has inefficiencies, some of which yield a greater cost burden to patients and provide for suboptimal incentives for use of some drugs. This issue is exemplified by the gross-to-net bubble, that is, the difference between the published list price of drugs and the net price following rebates and other reductions.

Among other factors contributing to the issue of cost highlighted by participants are the unintended consequences of some attempts to provide greater equity. They suggested that strategies to shift the cost burden and ensure access in the form of patient financial support like copay coupons, manufacturer and independent patient assistance programs (PAPs), and point-of-sale rebates (Table 1), for example, can be perceived as marketing or an attempt to undermine formulary and benefit structures. As a result, these have prompted countermeasures like copay accumulator and copay maximizer programs (Figure 1), which some were concerned can add additional layers of complexity and may exacerbate the risk of financial hardship to patients.

Participants commented that the often underappreciated interconnectivity of the health care system contributes to any potential reforms of these underlying issues This can be illustrated with the many attempts to improve transparency, which alone may not improve affordability. Any effective solution will need to address both transparency and affordability, as well as the issue of shared risk. It will also require implementing policy strategies (Table 2) across several areas, such as addressing high OOP costs and high list prices, utilizing external reference pricing, and allowing the employment of available negotiation tools.

Additional opportunities identified by participants focused on stakeholders placing patients at the center of decision making and on benefit changes. Efforts to educate patients about the potential OOP costs of their various options before selecting a benefit was seen by the participants as worthwhile, as would be increased focus on digitization enabling real-time decision support and benefit checks for clinicians, pharmacists, and patients when choosing a therapy. Improving the predictability of OOP costs was also considered by the group to be beneficial to patients. This could be done via various mechanisms such as fixed copays rather than cost shares; copays or cost shares based on the net price versus the list price; and copay smoothing, which would distribute costs more evenly throughout the year.

Finally, opportunities to realign incentives via valuebased payment using standardized metrics and alternative payment models such as a subscription to access high-cost drugs were suggested.

\section{Solutions to Improve Transparency, Understanding, and Management of Patient Drug Costs}

Transparency is a widely discussed topic relative to better understanding and management of patient drug costs. Solutions to improve transparency are a focus of many including those within health care and those making health care policy. A challenge highlighted by participants in conversations about transparency, however, is that the term has different meanings to various stakeholders, and they discussed several examples. To prescribers and patients, for instance, transparency generally relates to understanding the coverage of drug options and which will be the best for them, as well as to being able to predict the associated OOP costs of these options to determine their affordability. To those designing benefits, transparency can mean certainty that patients will adhere to those prescribed benefits, a certainty that can be seen as disrupted by some market practices, such as offering patient financial support programs (Table 1). Additionally, to employers and legislators among others, transparency may refer to visibility into the calculation, application, and net effect of rebates on list 


\begin{tabular}{|c|c|}
\hline TABLE 2 & $\begin{array}{l}\text { Select Drug Pricing Policy Reform } \\
\text { Concepts/Programs Considered by } \\
\text { Participants }\end{array}$ \\
\hline Proposal & Description/Example \\
\hline $\begin{array}{l}\text { Restrict price } \\
\text { increases }\end{array}$ & $\begin{array}{l}\text { Restrict price increases to inflation levels, } \\
\text { such as the Consumer Price Index for All Urban } \\
\text { Consumers (CPI-U). Example: CMS proposed } \\
\text { to revoke a drug's "protected class” coverage } \\
\text { requirement if the list price increased faster } \\
\text { than inflation over a defined time. }\end{array}$ \\
\hline $\begin{array}{l}\text { External } \\
\text { reference pricing }\end{array}$ & $\begin{array}{l}\text { International Price Index (IPI): Prices for } \\
\text { physician-administered drugs covered under } \\
\text { Medicare Part B would be based on those in a } \\
\text { set number of countries. IPI methodology would } \\
\text { also involve changes to the existing distribution } \\
\text { model for physician-administered drugs. }\end{array}$ \\
\hline Negotiating tools & $\begin{array}{l}\text { Federal government would have authority to } \\
\text { negotiate prices for prescription drugs. } \\
\text { States would have flexibility to exclude certain } \\
\text { drugs from coverage. }\end{array}$ \\
\hline $\begin{array}{l}\text { Improve } \\
\text { transparency }\end{array}$ & $\begin{array}{l}\text { Reform the Sunshine Act to include payments } \\
\text { made to patient groups and free drug samples. } \\
\text { State-level drug transparency laws: } \\
\text { 1. Net price reporting (by manufacturers, } \\
\text { wholesaler, pharmacy, PBM, and/or insurer). } \\
\text { 2. Reporting of aggregate rebates (by } \\
\text { manufacturers, wholesaler, pharmacy, } \\
\text { PBM, and/or insurer). } \\
\text { 3. Provision of advanced notice of list price } \\
\text { increases by manufacturers. } \\
\text { 4. Drug price transparency in advertisements. }\end{array}$ \\
\hline $\begin{array}{l}\text { Benefit } \\
\text { limitations }\end{array}$ & $\begin{array}{l}\text { State legislation for copay caps (e.g., insulin } \\
\text { cost cap). } \\
\text { State legislation for caps on OOP costs. }\end{array}$ \\
\hline $\begin{array}{l}\text { Increase } \\
\text { competition }\end{array}$ & State-led generic drug manufacturing. \\
\hline $\begin{array}{l}\text { Supply chain } \\
\text { regulation }\end{array}$ & $\begin{array}{l}\text { Regulation of markup in the pharmaceutical } \\
\text { supply and distribution chain. } \\
\text { Import more affordable medications from } \\
\text { abroad. }\end{array}$ \\
\hline
\end{tabular}

CMS=Centers for Medicare \& Medicaid Services; $O O P=$ out of pocket; $\mathrm{PBM}=$ pharmacy benefit manager .

prices and overall spending on drugs, as well as the end impact to patients.

Regardless of these different perspectives, though, there was general agreement among participants that attempts to increase and improve transparency need to be meaningful. Patient education, as an example, is a limited solution, and the wider availability of web-based transparency tools may only provide substantive benefit to some, such as those already educated and invested in their health care.
Additionally, some tools meant to provide transparent, low-cost options such as freely available discount programs operate outside of the member's benefit and related OOP cost calculations, which may actually be counterproductive to the overall lowering of their costs.

Despite these limitations, participants suggested that there are opportunities to achieve greater transparency as well as understanding and managing patient drug costs. Utilizing technology in different ways such as to employ electronic prior authorization capabilities, real-time benefit investigations, and more interactive and patient-centered tools, for instance, could all help with this goal. Offering interactive benefit videos that can provide patients with greater understanding of what they can expect from their benefits at the time they are purchasing them was one other example highlighted.

Patient financial support programs (Table 1) may also assist patients in this area, in particular with regard to management of their drug costs. The value of these programs listed by participants included increased access via lower OOP costs, potentially improved adherence to drug therapy leading to better outcomes and lower total costs, and the benefit of wrap-around services (e.g., travel assistance) that are a part of some PAPs specifically. As such, the possibility of a central database of programs was suggested making the program options more readily accessible to the patient or other members of the care team. Although, participants did acknowledge that these programs may also have associated consequences like potential tax implications, impacts to insurance benefits and the resulting response (e.g., copay accumulators), higher overall prices to recoup support dollars, and incompatibility with Medicare and Medicaid, possible decreased adherence if the funds are exhausted. They may drive higher-cost prescribing or lead to patients asking for specific therapies.

\section{The Future of Affordability in Pharmacy}

The future of drug affordability for patients relies on many stakeholders and will likely need to involve, among other things, a reimagining of some current operational practices and employment of innovative benefit design proposals (Table 3). PBMs were a key focus of this discussion, for example, both regarding the ways they have traditionally operated, as well as how they can evolve to have additional positive impact on the health care system. Currently, PBMs have considerable control over the price of drugs, for example, generic drugs via the use of Maximum Allowable Cost lists and brand drugs via the negotiation of net price. In some cases, they 


\begin{tabular}{l|l}
\multicolumn{1}{c|}{ TABLE 3 } & $\begin{array}{l}\text { Possible Benefit Design Solutions } \\
\text { to OOP Costs Considered by the } \\
\text { Participants }\end{array}$ \\
\hline $\begin{array}{l}\text { Proposal } \\
\text { Copayments } \\
\text { instead of } \\
\text { coinsurance }\end{array}$ & \begin{tabular}{l}
\multicolumn{1}{c}{ Description/Example } \\
of coinsurance and deductibles to improve \\
patients' access and adherence to treatments by \\
providing more predictability for OOP expenses.
\end{tabular} \\
\hline $\begin{array}{l}\text { Share rebates } \\
\text { with patients }\end{array}$ & $\begin{array}{l}\text { Base cost-sharing calculations on the plan's net } \\
\text { prices (i.e., postrebate) for drugs rather than } \\
\text { on drug prices at the point of sale (i.e., before } \\
\text { rebates and price concessions are received). }\end{array}$ \\
\hline $\begin{array}{l}\text { Align cost-sharing } \\
\text { to reflect value }\end{array}$ & $\begin{array}{l}\text { Use value-based formularies for prescription } \\
\text { drugs to lower the OOP cost for high-value } \\
\text { drugs. }\end{array}$ \\
\hline $\begin{array}{l}\text { Limit OOP } \\
\text { spending }\end{array}$ & $\begin{array}{l}\text { Annual OOP spending maximum for outpatient } \\
\text { prescription drugs and copay caps (e.g., insulin } \\
\text { cost cap). }\end{array}$ \\
\hline $\begin{array}{l}\text { Preferred } \\
\text { specialty tier }\end{array}$ & $\begin{array}{l}\text { Incentivize beneficiaries to choose lower-cost } \\
\text { drug options and implement a maximum allow- } \\
\text { able cost sharing that would apply to the higher } \\
\text { cost-sharing specialty tier (e.g., between 25\% } \\
\text { and 33\%) }\end{array}$ \\
\hline OOP=out-of-pocket. & \begin{tabular}{l} 
and \\
\hline
\end{tabular}
\end{tabular}

may also have misaligned incentive to reduce drug prices given the primary ways they attain profit (e.g., mail order and specialty pharmacy dispensing, retail prescription spread, retained pharmaceutical manufacturer incentives), which may result in higher costs passed to the patient.

Successful PBM reform, it was suggested, would have to address the profit conflict of interest and would have to move away from average wholesale price as the standard of drug pricing. The first factor could be achieved by instituting a profit model based on cost-plus pricing or a flat administrative fee, whereas the second factor would require the utilization of what was described as a more rational drug-pricing standard based on the real economics of the supply chain such as the National Average Drug Acquisition Cost (NADAC) pricing benchmark, which is already in use for Medicaid.? The NADAC is derived from surveys of community pharmacy acquisition costs and was developed to better reflect what they actually pay.?

Expanding the role of ancillary members of the health care team was also identified as important to the future of affordability. Patient advocates or pharmacy technicians, for instance, can serve the function of performing real-time benefit investigations and can spend the necessary time that prescribers may not have to help patients understand their drug options and to locate any available financial support.
Other thoughts around areas of focus in the future included evaluating total cost of care in relation to better patient outcomes and increasing interoperability, portability, and activism to support the overall ease of utilizing insurance benefits for patients.

Finally, participants suggested that there are a number of benefit and nonbenefit design options that could be considered. These include some already being employed that could be expanded or improved. Value-based formularies, that is, those based equally on clinical outcomes and costs, were highlighted as a best practice, although standardized concepts around value and how to quantify it would need to be defined. Additionally, separate tiers for preferred specialty drugs or biosimilars could be utilized to encourage their use and lower patient OOP costs. Flat copays versus coinsurance, smoothing of copays over time, and copay caps for specific drugs were also identified as encouraged practices to help patients better anticipate their cost shares. Outside the pharmacy benefit design specifically, ancillary benefit coverage like meal services and caregiver support have a role in improving adherence and outcomes, as does pharmacogenomics testing to reduce trial and error and implementing technology solutions like text/chat functions.

\section{Conclusions}

Given the current, escalating cost of prescription drugs in the United States, it is clear that patients face significant challenges. Ultimately, participants recognized that many current pharmaceutical affordability issues are related or are in response to other elements of the health care system. For example, there would be less need for patient financial support programs if drug OOP costs were more predictable and affordable for patients. Thus, addressing only 1 policy area will likely not be as successful as implementing strategies simultaneously and across multiple sectors (e.g., high list prices, OOP costs, external reference pricing, and negotiation tools). Participants supported comprehensive approaches to address these complex and inter-related issues.

Overall, participants called for greater transparency and better alignment among all health care industry stakeholders to place patients in the center of decision making and for any benefit changes or reforms to consider patient access, affordability, and adherence. A key concept identified to improve predictability for patients was more even distribution, or smoothing, of OOP costs throughout the year. Additionally, making pharmacy benefits easier to understand for patients will support improved transparency around OOP expenses, the relationship between copays and premiums, and the effect of copay coupons. 
Health care leaders will also need to re-evaluate the portability of benefits and provide better education at the time of benefits selection, which will help patients better understand their costs and opportunities.

\section{DISCLOSURES}

This forum was sponsored by Merck, Pfizer, PhRMA, and Takeda. These proceedings were prepared as a summary of the forum to represent common themes; they are not necessarily endorsed by all attendees nor should they be construed as reflecting group consensus.

\section{ACKNOWLEDGMENTS}

This AMCP Partnership Forum was moderated by Cliff Goodman, PhD. These proceedings were written by Bridget Flavin, PharmD, Founder, Connected Content.

\section{REFERENCES}

1. Centers for Medicare \& Medicaid Services. National health expenditure projections 2019-2028: forecast summary. 2019. Accessed November 22, 2020. https://www.cms.gov/files/document/ nhe-projections-2019-2028-forecastsummary.pdf

2. Seymore B. Taming the trend: managing costs of specialty pharmaceuticals for insurers. Pharmacy Times. March 23, 2020. Accessed November 22, 2020. https://www.pharmacytimes.com/news/ taming-the-trend-managing-costs-of-specialty-pharmaceuticals-for-insurers

3. Massachusetts Municipal Association. Gene therapies offer breakthrough results but extraordinary costs. March 18, 2020. Accessed November 22, 2020. https://www.mma.org/ gene-therapies-offer-breakthroughresults-but-extraordinary-costs/

4. Tikkanen R, Abrams MK; The Commonwealth Fund. U.S. health care from a global perspective, 2019: higher spending, worse outcomes? January 30, 2020. Accessed November 22, 2020. https://www.commonwealthfund.org/ publications/issue-briefs/2020/jan/ us-health-care-global-perspective-2019
5. Centers for Medicare \& Medicaid Services. CMS Office of the Actuary releases 2018 national health expenditures [press release]. December 5, 2019. Accessed November 21, 2020. https:// www.cms.gov/newsroom/press-releases/ cms-office-actuary-releases-2018-national-health-expenditures

6. U.S. Department of Labor, Bureau of Labor Statistics. Real earnings-July 2020 [news release]. November 12, 2020. Accessed November 21, 2020. https:// www.bls.gov/news.release/pdf/realer.pdf

7. Centers for Medicare \& Medicaid Services. Methodology for calculating the National Average Drug Acquisition Cost (NADAC) for Medicaid covered outpatient drugs. November 2013. Accessed November 21, 2020. https:// www.medicaid.gov/medicaid-chipprogram-information/by-topics/ prescription-drugs/ful-nadac-downloads/nadacmethodology.pdf

8. Drug Channels Institute. Copay accumulator update: widespread adoption as manufacturers and maximizers limit patient impact. September 18, 2018. Accessed November 21, 2020. https:// www.drugchannels.net/2018/09/copayaccumulator-update-widespread.html 